\title{
Cell Phone Banking Adoption in South Africa
}

\author{
Richardson Shambare (Corresponding author) \\ Dept. of Management \& Entrepreneurship, Tshwane University of Technology \\ PO Box x680, Pretoria, South Africa
}

Tel: 27-74-459-9902Ｅ-mail: shambarar@tut.ac.za

Received: October 17, $2011 \quad$ Accepted: October 30, 2011 doi:10.5296/ber.v1i1.1144

\begin{abstract}
Despite the exponential growth in cell phone usage in South Africa, from 13 million subscribers in 2002 to at least 49 million subscribers today, uptake of cell phone banking in the same period lags. Utilising Rogers' innovation adoption framework, this research examines banking consumers' perceptions of cell phone banking attributes, and how these may affect adoption. A survey of 124 cell phone users from Gauteng, Mpumalanga, and Limpopo Provinces participated in the study. Results indicate an improvement in cell phone banking uptake compared to past years. Perceptions of risk and security concerns appear to slow the adoption rate. While banking institutions have done a lot in launching cell phone banking, focussing attention on in-house promotion and customer demonstrations of cell phone banking may further improve adoption rate.
\end{abstract}

Keywords: Adoption, Cell phone banking, South Africa 


\section{Introduction}

In the last three decades, advancements in information and communication technologies (ICTs) forever revolutionised banking (Devlin, 1995). Once, a bank was confined to four walls and a roof; today that is no more. Automated teller machines (ATMs), debit cards, the Internet, and mobile phones now can all represent a bank (Jayamaha, 2008), in that consumers can use these devices to conduct banking independent of a bank branch. Banking technology experts including Devlin (1995) and Devlin and Yeung (2003) agree, and explain how technology has tipped remote (anytime and anywhere) banking into the mainstream Western culture. For instance, ATMs or cash machines iconify $21^{\text {st }}$ Century banking institutions. To some extent, this also applies to many African countries. For that reason, Brown, Cajee, Davies, and Stroebel (2003) posit that the widespread adoption of ICTs and mobile phones in South Africa provides opportunities for banking services to reach critical masses of consumers. The latter is particularly applicable even in remote areas inaccessible to bank branches (Kumar \& Gupta, 2008). Despite this, uptake of cell phone banking (CB) is still low.

Latest statistics reveal that the South African cell phone market surpassed 48.5 million subscribers by the end of 2010 (Business Wire, 2010; Central Intelligence Agency [CIA], 2010), up from 45 million and 13 million subscribers in 2008 and 2002, respectively (Brown et al., 2003). For a developing nation of 50 million people, a mobile coverage of about 97 per cent is impressive given that cellular telephony was only introduced in South Africa in 1994 (International Telecommunications Union [ITU], 2011). Such an exponential growth, naturally, presents enticing propositions for marketing and business. More so the financial services sector in particular the marketing of remote banking technologies such as mobile banking.

Although Brown et al. (2003) argue that increased diversity of cell phone improves CB adoption, such claims still remain untested and unverified. Despite extensive CB research having being conducted in the West, very little research in the area has been done in South Africa. Literature searches by the authors, in academic journals on cell phone banking in South Africa, resulted in only one study - Brown et al. (2003). Given that ICTs are developing at phenomenal rates, the context of cell phone banking, today, may have differed significantly from 2003. It is therefore opportune to examine mobile banking in South Africa.

Given the paucity of empirical research, data on CB customers is scanty. It is difficult to ascertain consumer motivations for adopting or rejecting CB. Building on the study by Brown et al. (2003) which considered predictors of mobile banking in South Africa's Western Cape Province, this study extends the study to three other South African provinces: Gauteng, Mpumalanga, and Limpopo.

The remaining sections of the paper are as follows: the following section discusses cell phone banking in South Africa. Next, the mobile banking adoption framework is presented. The methodology and findings sections are presented followed by the discussion of results and concluding remarks. 


\section{Cell phone banking in South Africa}

The South African big four banks (ABSA, FNB, Nedbank, and Standard Bank) all provide cell phone banking services. Similar to Internet banking (IB) or ATMs, customers can access their accounts and perform various banking activities (namely transfer funds, check balances, pay bills, and apply for loans). Overall, FNB estimates that some 1.29 million South Africans are using mobile banking technology to manage their accounts (Pienaar, 2009). Brown et al. (2003) found that approximately 6 per cent of South Africa's 13 million cell phone subscribers in 2002 had used mobile banking services. Latest industry literature reports that more South Africans, today, prefer using cell phones over other self service banking technologies (Mobile-Financial.com 2009; Pienaar, 2009; SouthAfrica.info, 2007; 2009). Pienaar (2009) argues that banking customers are more willing to adopt cell phone banking than other self-service banking channels. To illustrate some 28 per cent of banking customers use mobile banking services compared to about 16 per cent that utilise Internet banking (SouthAfrica.info, 2009).

While industry literature is abounding with accounts of an upsurge in mobile banking usage, most of what is known about $\mathrm{CB}$ and its adoption is reported in scientific literature from the developed world. While this literature provides valuable lessons, there is still limited research in the area of adoption of banking technologies undertaken in developing countries. Research on the factors influencing adoption of cellular banking is still limited. Thus, it is opportune to investigate factors influencing the adoption of cell phone banking. In the following section, the $\mathrm{CB}$ adoption framework is discussed.

\section{Cell phone banking adoption framework}

Consistent with Brown and colleagues, this study utilises Rogers' (1995) Innovation decision model (IDPM). This model has been tested and widely applied in numerous settings including education, psychology, and marketing (Agarwal \& Prasad, 1998; Robertson, 1967; Rugimbana \& Iversen, 1994; Seligman, 2006; Shih \& Fang, 2004; Taylor \& Todd, 1995; Meuter et al., 2005). The literature consistently illustrates that adoption of new innovations is influenced by potential adopters' perceptions towards the innovation (Rogers, 1995; Rugimbana \& Iversen, 1994). More specifically Rogers (1995) explains:

Innovations that are perceived by individuals as having greater relative advantage, compatibility, trialability, and less complexity will be adopted more rapidly than other innovations. Past research indicates that these five qualities are the most important characteristics of innovations in explaining the rate of adoption (Rogers, 1995:16).

The innovation characteristics are defined next.

Relative advantage: - Agarwal and Prasad (1998) demonstrate that the advantage an innovation has relative to another method is positively related to its rate of adoption. It is therefore possible to suggest that the advantages that cell phone banking offers over other banking methods would affect its rate of adoption. Among these advantages are anytime and 
anywhere banking that is convenient, since banking customers can access their accounts using their cell phones.

Perceived compatibility: - Compatibility refers to how well a technology fits with an individual's working and lifestyle, values, and needs (Rogers, 1995). In the context of cell phone banking, compatibility is the extent to which cell phone banking is in line with how the banking customers live their lives. For example, if a customer uses her cell phone rather frequently and for numerous functions including calendar, camera, and communicating, they have a higher degree of compatibility than someone who rarely uses cell phones. As a result, those who feel banking via cell phones is compatible with their lifestyle would more likely adopt cell phone banking.

Perceived complexity: - The level of difficulty of using an innovation is inversely related to its adoption (Meuter et al., 2005; Taylor \& Todd, 1995). Consequently, the greater the perceived complexity of conducting banking via the cell phone, the less likely its adoption will be.

Trialability: - Potential adopters of a new technology who are allowed to experiment first will feel comfortable with the technology, and thus are more likely to adopt it (Agarwal \& Prasad, 1998; Tan \& Teo, 2000). Thus, the adoption of cell phone banking is more likely if the technology is demonstrated to the user or if it can be used on a trial basis first.

Perceived risk: One of the major influencing factors around the establishment and use of new technologies for financial transactions is that of security and trust (Brown et al., 2003; Pienaar, 2010). The need for security of personal details and financial information is therefore critical to the success of cell phone banking. Some of the risks associated with $\mathrm{CB}$ and banking, in general, are the possibility of losing money to fraud. As a result, the lower the perception of risk involved in using cell phone banking, the more likely that it will be adopted.

Self-efficacy: refers to the confidence potential adopters have in their ability to use a specific technology (Taylor \& Todd, 1995). The higher the individuals' experience and skill of using cell phone, the higher the chances the technology will be adopted.

Facilitating conditions (technology support): This construct may be interpreted to include support from both the cellular service providers as well as from the banks (Brown et al., 2003). Cell phone banking is more likely to be adopted if there are better facilitating conditions.

Although Rogers (1995) identifies five key predictors of adoption, recent studies confirm that three of these: relative advantage, compatibility, and complexity have consistently proved to be stable predictors across multiple disciplines (Agarwal \& Prasad, 1998; Meuter et al., 2005; Rugimbana \& Iversen, 1994). For that reason, this study considers these three as key independent variables. 


\subsection{Conceptual model}

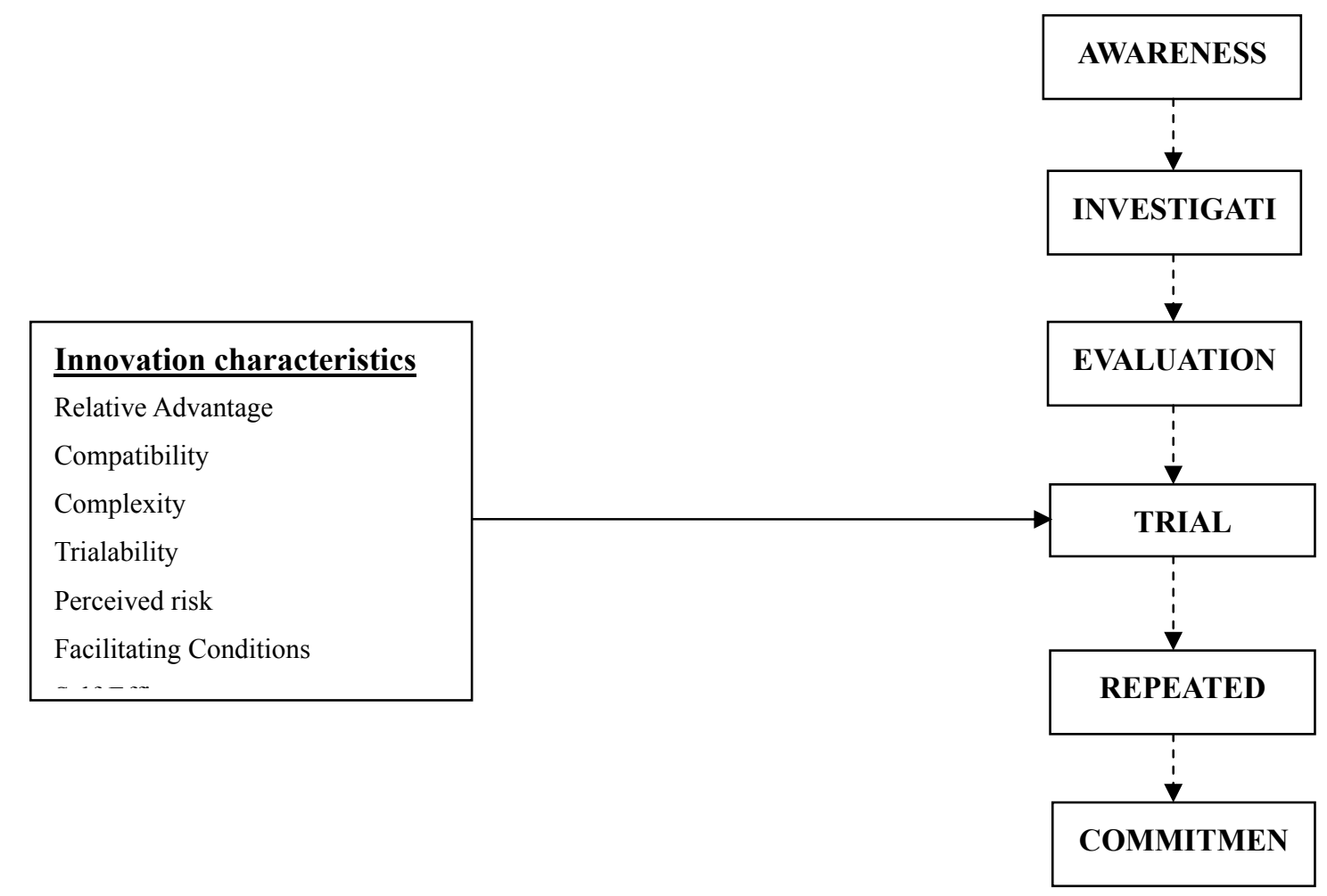

Figure 1. CB adoption conceptual model

As shown in Figure 1, adoption, according to Rogers (1995), is a six-step process from awareness to commitment. Meuter et al. (2005:64) illustrates that "getting customers to try a new technology is a key barrier [to adoption]. If overcome, adoption is almost guaranteed. Numerous studies including Meuter et al. (2005) and Agarwal and Prasad (1998) considered trial as the dependent variable in adoption. For the purposes of this study, 'CB Trial' was operationalised to be the focal dependent variable representing adoption. Accordingly, trial was measured using a single-item question assessing whether respondents had tried using CB or not.

\subsection{Research question and hypotheses}

The advantages of $\mathrm{CB}$ are well-documented in the literature - convenience, anytime-anywhere banking, privacy, and saving time (Brown et al., 2003; Devlin \& Yeung, 2003). In reality though these advantages for both consumers and service providers can only be realised when consumers adopt and use the service (Agarwal \& Prasad, 1998), which at this point in time appears to be low. Consequently, the research questions for the study are formulated as follows:

RQ1: Which factors influence cell phone banking?

RQ2: What are most important factors affecting cell phone banking adoption? 
In turn, the following hypotheses were formulated, and provided basis for data collection and data analysis.

$\mathbf{H}_{1}$ : the greater the perceived complexity of using $C B$, the less likely that it will be adopted.

$\mathbf{H}_{2}$ : the greater the perceived compatibility of using $C B$, the more likely that it will be adopted.

$\mathbf{H}_{3}$ : the greater the perceived relative advantage of using $C B$, the more likely that it will be adopted.

$\mathbf{H}_{4}$ : the greater the perceived trialability of using $C B$, the more likely that it will be adopted.

$\mathbf{H}_{5}$ : the greater the perceived self-efficacy of using $C B$, the more likely that it will be adopted.

$\mathbf{H}_{6}$ : the greater the facilitating conditions of using $C B$, the more likely that it will be adopted.

$\mathbf{H}_{7}$ : the greater the perceived risk of using $C B$, the more likely that it will be adopted.

\section{Research methodology}

A cross-section survey method was used. Data were collected using Survey Monkey, an online survey system was used to administer the instrument. Using Survey Monkey provided ease of access to respondents from different locations.

\subsection{Sample}

Since the study was concerned with mobile banking, all individuals with a bank account or a cell phone potentially constituted the sampling frame (Blumberg Cooper, \& Schindler., 2008). Given the challenges of drawing a random or other probabilistic sample, the snowballing technique was utilised. Such a technique minimised sampling bias and at the same time maximised the sample's representativeness (Blumberg et al., 2008). To target as many consumers as possible from a wide range of backgrounds and taste (Calder et al., 1981), the online questionnaire system, Survey Monkey, was used. Researchers sent emails with the Survey Monkey link to 15 banking customers (10 in Gauteng, 3 in Limpopo, and 2 in Mpumalanga) informing them of the study and the questionnaire. In turn these participants notified potential respondents on their email lists, and they consecutively forwarded the link to other banking customers. This process was repeated numerous times between August and October 2010, in which 152 respondents completed the questionnaire. Of these 124 questionnaires were fully completed and usable for analysis. The remaining instruments were either spoilt or had too many missing values. Table 2 provides further details pertaining to the participants' demographic characteristics.

\subsection{Questionnaire}

The instrument used in Brown et al., (2003) was adapted for this study. Table 1 details the adapted questionnaire. 
Table 1. Questionnaire Adaptation

\begin{tabular}{|c|c|c|}
\hline $\begin{array}{c}\text { Original Brown et al (2003) } \\
\text { Questionnaire }\end{array}$ & Adaptation & Rationale \\
\hline $\begin{array}{l}\text { Section A: } \\
\text { Included questions about WAP } \\
\text { and WIG features on } \\
\text { respondents' cell phones }\end{array}$ & $\begin{array}{l}\text { WAP-enabled and WIG-enabled } \\
\text { questions were removed. }\end{array}$ & $\begin{array}{l}\text { o Current technology of CB no longer } \\
\text { requires WIG-enabled and } \\
\text { WAP-enabled cell phones to support } \\
\text { CB. } \\
\text { o The USSD technology similar to that } \\
\text { used to recharge airtime is now in } \\
\text { use }\end{array}$ \\
\hline $\begin{array}{l}\text { Section B: } \\
\text { Included several questions } \\
\text { about banking products and } \\
\text { services }\end{array}$ & $\begin{array}{ll}\text { o } & \text { Combined some banking } \\
\text { products- e.g. current and } \\
\text { cheque account were } \\
\text { collapsed into one category } \\
\text { o Included a list of current } \\
\text { banking institutions }\end{array}$ & $\begin{array}{l}\text { o To be consistent with current } \\
\text { banking trends and terminology, as } \\
\text { advised by banking experts } \\
\text { o To provide a realistic list of banks }\end{array}$ \\
\hline Section C: & $\begin{array}{l}\text { Included more services that } \mathrm{CB} \\
\text { is now handling e.g. paying } \\
\text { traffic fines and municipality } \\
\text { bills }\end{array}$ & To present a realistic account of CB. \\
\hline $\begin{array}{l}\text { Section D: } \\
\text { Income quoted on an annual } \\
\text { basis }\end{array}$ & $\begin{array}{ll}\text { o } & \text { Modified monthly income } \\
& \text { to a monthly basis } \\
\text { o } & \text { Included a question on } \\
\text { respondents' religion }\end{array}$ & $\begin{array}{l}\text { o To be consistent with many South } \\
\text { African studies } \\
\text { o The account for the importance of } \\
\text { religion, as it is increasingly being } \\
\text { considered an important predictor in } \\
\text { consumer behaviour }\end{array}$ \\
\hline
\end{tabular}

The questionnaire was pre-tested on 10 undergraduate and postgraduate students to ensure that the questions would be understood by the target audience. The final questionnaire included a cover letter, instructions for completion, and four sections of structured questions. A likert scale $(1=$ Strongly Disagree and $5=$ Strongly Agree $)$ was used.

\subsection{Data Analysis}

Consistent with research objectives and methodology, a structured questionnaire was used to collect quantitative data. Therefore, statistical analysis was appropriate. PASW (SPSS) v.18 was used to perform the following analyses (Field, 2009; Pallant, 2010):

o Descriptive measurements to describe the data and sample;

o Reliability analysis using Cronbach's alpha coefficient to measure internal consistency of the various sub-scales in the questionnaire;

o Pearson's chi-square test to measure relationships between various variables;

o Factor Analysis to reduce items into latent dimensions existing in the scales

o Multiple regression and Logistic regression to test hypotheses and answer research questions. 


\section{Results}

The use of Survey Monkey allowed for the participation of a wide range of consumers from different backgrounds (Calder et al., 1981). Table 2, below, illustrates the participants' demographic characteristics.

Table 2. Demographic Profile

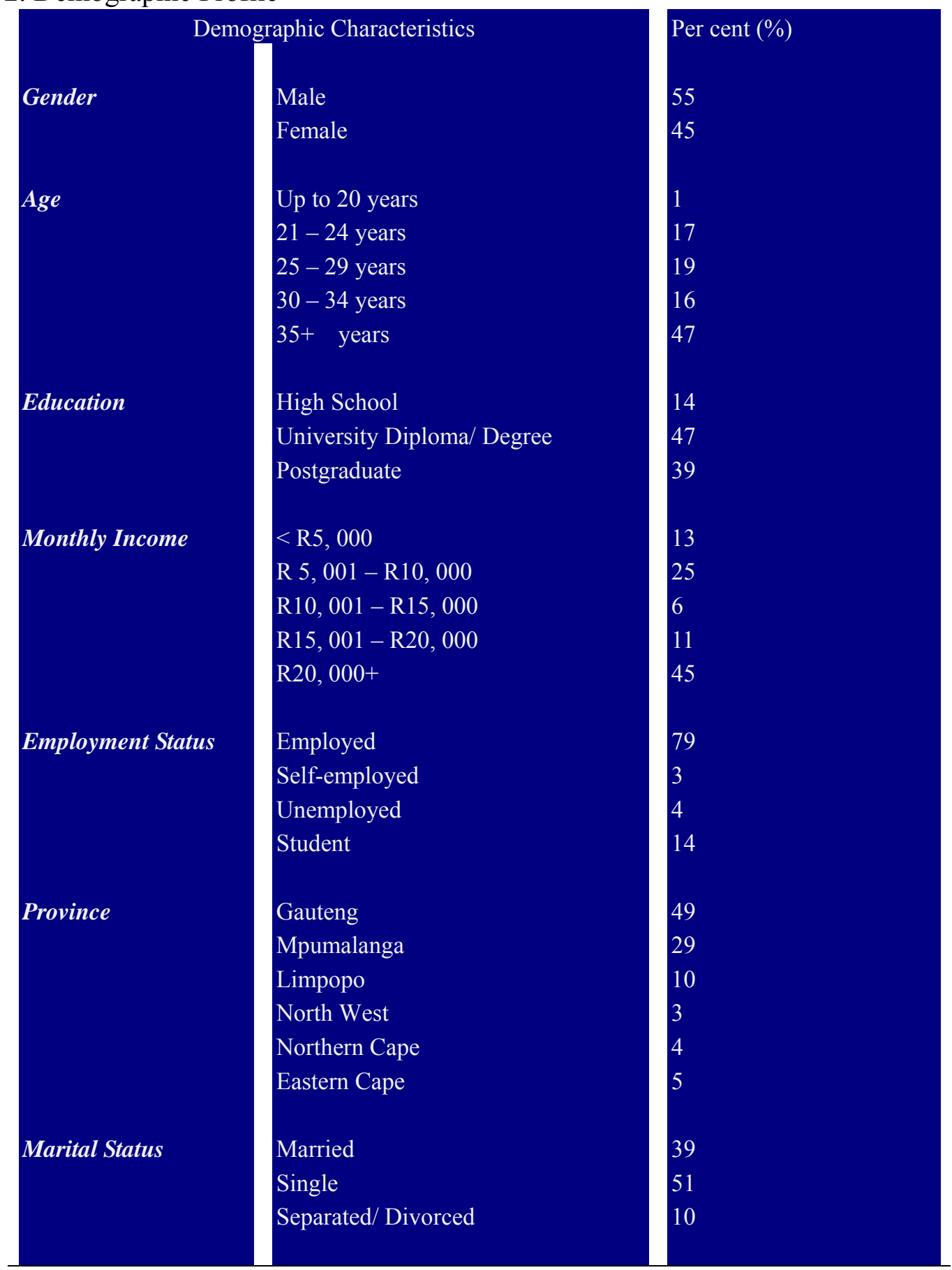

\subsection{Respondents'banking profile}

Tables $3 \mathrm{a}$ and $3 \mathrm{~b}$ summarise respondents' banking profile. 
Table 3a. Types of Accounts used

\begin{tabular}{l|l|l|}
\hline Bank & Count & Percentage \\
Savings Account & 71 & 57.7 \\
Current Account & 90 & 73.2 \\
Fixed-Deposit & 15 & 12.2 \\
Personal Loan & 18 & 14.6 \\
Car/ Home Loan & 31 & 25.2 \\
Other Account & 10 & 8.1 \\
\hline
\end{tabular}

Table 3b. Extent of channel use

\begin{tabular}{l|c|c|c|c}
\hline & Mean & Min. & Max. & Std. Dev. \\
Telephone & 4.8 & 1 & 6 & 1.77 \\
Bank branch & 4.6 & 1 & 6 & 0.75 \\
Cell phone Banking & 4.1 & 1 & 6 & 1.93 \\
Internet Banking & 3.8 & 1 & 6 & 1.74 \\
Store/ shop & 3.7 & 1 & 6 & 1.48 \\
ATM & 3.4 & 1 & 6 & 1.01 \\
\hline
\end{tabular}

$(1=$ never, $6=$ daily $)$

\subsection{Scale Measurement}

\subsubsection{Construct reliability}

Using the Cronbach's alpha $(\alpha)$ coefficient, the measuring instruments were tested for internal consistency and construct reliability. Item selection and scale purification using inter-item and item-to-total correlations were used to measure internal consistency for questions (Pallant, 2010). With the exception of Section D (demographic information), all other scales (see Table 4) were tested for reliability. According to Tan and Teo (2000), perception scales yielding a Cronbach's alpha of at least 0.6 are regarded as reliable and internally consistent.

Cronbach's alphas of the sub-scales ranged from 0.690 (Relative Advantage) to 0.925 (Self-efficacy) (Table 4), which indicate an acceptable internal consistency and reliability measures for the questionnaire (Field, 2009; Tan \& Teo, 2000).

Table 4. Cronbach's alpha $(\alpha)$ for the sub-scales

\begin{tabular}{|l|c|c|c|}
\hline \multicolumn{1}{|c|}{ Sub-scale } & $\begin{array}{c}\text { Cronbach's } \\
\text { alpha }(\boldsymbol{\alpha})\end{array}$ & Mean & $\begin{array}{c}\text { No. of items } \\
\text { retained }\end{array}$ \\
\hline Self-Efficacy & .925 & 3.776 & 3 \\
\hline Compatibility & .907 & 3.297 & 2 \\
\hline Trialability & .874 & 3.592 & 3 \\
\hline Risk & .873 & 3.174 & 3 \\
\hline Complexity & .814 & 2.336 & 2 \\
\hline Facilitating Conditions & .778 & 3.613 & 2 \\
\hline Relative Advantage & .690 & 3.450 & 2 \\
\hline Entire Scale & .870 & & 17 \\
\hline \multicolumn{3}{|c|}{ Total } \\
\hline
\end{tabular}




\subsubsection{Construct Validity}

Factor analysis using the varimax rotation was used to ascertain construct validity of each of the constructs (sub-scales) with multiple-item measures. The 17 retained-items (Table 4) yielded a five-factor structure with eigenvalues greater than 1, explaining 73 per cent of the variance. As in Brown et al. (2003), risk and complexity loaded onto Factor 1. A correlation analysis revealed that risk and complexity were separate constructs, as the coefficient between them was $0.427(\mathrm{p}<.05)$ (Pallant, 2010). Self-efficacy loaded onto Factor 2. Factor 3 contained items from Trialability and Compatibility. Factor 4 also had cross loading with items from Facilitating Conditions and Compatibility loading on this factor. Relative advantage loaded onto Factor 5. After dropping, one item due to cross loadings, a subsequent factor analysis yielded yet another 5-factor structure accounting for 74 per cent of the variance. Overall these findings suggest that these factors were indeed separate constructs. Table 5 illustrates these constructs as well as their means, standard deviations, and correlations.

Table 5. Means, standard deviations, and correlations among variables

\begin{tabular}{|c|c|c|c|c|c|c|c|c|c|}
\hline Variable & Mean & $\begin{array}{l}\text { Standard } \\
\text { Deviation }\end{array}$ & 1 & 2 & 3 & 4 & 5 & 6 & 7 \\
\hline 1. Complexity & 2.34 & 1.054 & 1 & & & & & & \\
\hline 2. Risk & 3.17 & 1.105 & $.427^{* *}$ & 1 & & & & & \\
\hline 3. Self-efficacy & 3.78 & .953 & -.076 & $-.356^{* *}$ & 1 & & & & \\
\hline $\begin{array}{ll}\text { 4. } & \text { Technology } \\
\text { Support }\end{array}$ & 3.61 & .908 & -.006 & -.070 & $.425^{* *}$ & 1 & & & \\
\hline $\begin{array}{ll}\text { 5. } & \text { Relative } \\
& \text { advantage } \\
\end{array}$ & 3.45 & .982 & $-.188^{*}$ & $.298^{* *}$ & $.298^{* *}$ & $.319^{* *}$ & 1 & & \\
\hline 6. Trialability & 3.59 & .955 & .051 & $.472^{* *}$ & $.472^{* *}$ & $.262^{* *}$ & .168 & 1 & \\
\hline 7. Compatibility & 3.30 & .965 & -.079 & $-.305^{* *}$ & $.383^{* *}$ & $.319^{* *}$ & $.224^{*}$ & $.390^{* *}$ & 1 \\
\hline
\end{tabular}

$* \mathrm{p}<.01 ; \quad * * \mathrm{p}<.05$

\subsection{Tests of model and hypotheses}

To test the model and hypotheses, the authors utilised multiple regression and logistic regression analysis (Pallant, 2010). A series of direct logistic regression was performed to assess the impact of independent variables on the dependent variable (adopting/ rejecting CB). The model contained 7 independent variables (risk, complexity, self-efficacy, trialability, compatibility, facilitating conditions, and relative advantage) identified the factor analysis and depicted in Table 5. The binary regression model's goodness of fit model was significant $\left(x^{2}=30.392 ; \mathrm{p}<.0005\right)$, indicating that the model was able to distinguish between respondents who reported to have adopted CB from those who did not. The model explained between 24.9 per cent (Cox \& Snell R squared) and 33.5 per cent (Nagelkerke R squared) of the variance, with 73.6 per cent classification accuracy (Pallant, 2010). This indicates that approximately three-quarters of the sample were correctly classified as either using CB or not. Of the seven predictor variables, only two made unique statistically significant contribution to the model: relative advantage $(B=1.004$; Wald $=11.203 ; \mathrm{p}<.0001)$ and complexity $(\mathrm{B}=$ 
$-0.511 ;$ Wald $=3.913 ; \mathrm{p}<.05)$.

To further test these predictors, we analysed results using an independent-samples t-test to determine whether the means for each of the predictor variables identified in the model differed significantly between the trial and non-trial groups. The mean scores for relative advantage were 3.9151 and 3.0758 for $\mathrm{CB}$ users and non-CB users, respectively (t-value = $-5.104, p<.0001)$. Mean scores for complexity were 1.9717 and 2.6288 for CB users and non-CB users, respectively (t-value $=3.542 ; \mathrm{p}<.001$ ).

\subsubsection{Hypothesis testing}

The hypotheses formulated above were tested using multiple regression and logistic regression. There was support for two of the seven hypotheses, as follows:

$\mathbf{H}_{1}$ : $\quad$ the greater the perceived complexity of using $C B$, the less likely that it will be adopted.

$\mathbf{H}_{3}$ : $\quad$ the greater the perceived relative advantage of using $C B$, the more likely that it will be adopted.

Past research illustrates that compatibility, relative advantage, and complexity are consistently related to adoption (Agarwal \& Prasad, 1998; Meuter et al., 2005; Tornatzky \& Klein, 1982). Findings from this study indicate that two (complexity and relative advantage) of the three major factors are significant

\section{Discussion}

Overall, results suggest an increase in the rate of CB adoption among South African banking consumers. Some 43 per cent of the respondents indicated that they used their cell phones to access their bank accounts (Table 6). While the figure is almost half of those who own mobile phones, it is still a much better position compared to about 10 years ago, which was about 6 per cent.

Table 6. Cell phone and cell phone banking statistics

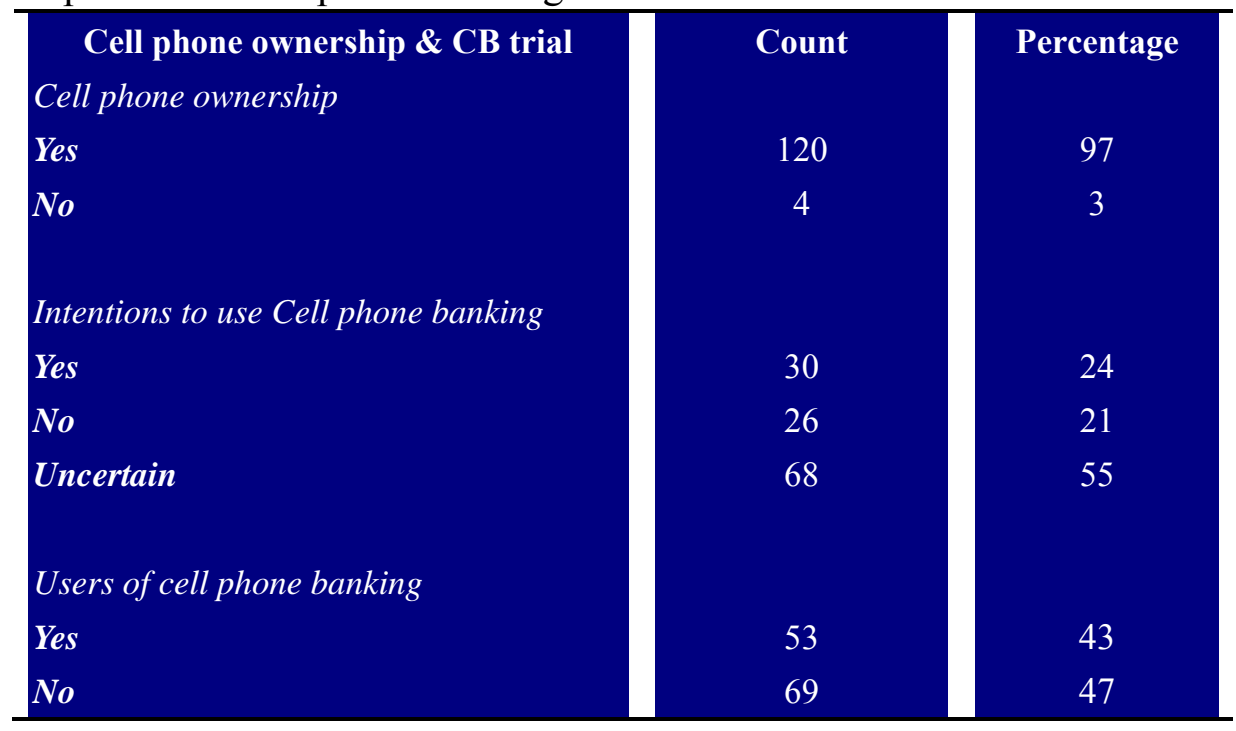


Since then, the technology supporting CB has improved and overall makes it easier for banking clients to access their accounts. Also, affordable Smartphone pricing coupled with availability of mobile services in local languages (MobiThinking, 2010) and a reliable network infrastructure United Nations Children's Fund (UNICEF, 2007) are contributing promoting cell phones and cell phone banking's ease of use.

In the recent past, there has also been an increase in the usage of mobile devices including cell phones to access social networking sites (SNSs) like Twitter and Facebook. Accordingly, SNS usage improves cell phone experience and self-efficacy (Bicen \& Cavus, 2010; Brown et al., 2003). With improved usage of cell phones, consumers are more likely to appreciate the relative advantage of cellular phones. It can also be assumed that perceptions of risk can also be managed with regular and frequent cell phone usage in different settings. Thus, these areas should be the focus of bank marketers' efforts to promote the uptake of cell phone banking. Thus promoting the awareness of cell phone banking through demonstrations will likely promote adoption. These trials and demonstrations can be conducted by bank employees within the branch. Therein, the consultants can clarify and answer questions for customers directly. Through these demonstrations, the perceptions of risk are likely to be mitigated.

Seven predictor variables were tested; only two provided statistically significant results relating to adoption. These results, suggesting that relative advantage and complexity are most important predictors seem satisfactory. This is because the literature consistently illustrates that three predictors (relative advantage, complexity, and compatibility) have been shown to influence adoption. Given that this research conforms to two of the 'big three' is exciting. The reason why compatibility might have not been a significant predictor could be the fact that the sample was mostly of mature customers (63 per cent of whom are 30 year or older), who might not use cell phones as much as a younger consumers. While cell phones are important devices, these consumers' lives do not revolve around the device. It is assumed that adults tend to view cell phones as practical devices for communication and also cell phone banking. In contrast, Hooper \& Zhou (2007) demonstrates that cell phones are more highly regarded by teenagers and students. The latter group of consumers view cell phones as status symbols and necessary appendages to life. Accordingly, their usage is highest among teenagers. As such, the compatibility construct might be more prevalent among youths and difficult to detect among for adult consumers.

\section{Limitations and future research}

Like many studies, this present study has some limitations. Firstly, the factors identified as possible influences on cell phone banking adoption are not exhaustive. Secondly, the sample included mostly respondents from three South African provinces, who also happen to be adult consumers. Future studies could also consider other factors such as familiarity and cost of cell phone banking, possibly to a sample of younger consumers such as students. Comparative studies that examine differences in adoption processes between different forms of banking channels, such as between Internet, telephone, and cell phone may also be conducted to better understand the adoption of self-service banking channels. 


\section{Conclusion}

Given that South African banking institutions have invested significantly in developing cell phone banking channels, it is important for these institutions to get return on investment. Therefore, understanding factors influencing CB adoption goes beyond just a mere interest or academic interest. It is likely to provide important strategic intelligence to financial institutions. This should also be considered given that cell phone banking offers a greater opportunity for spreading banking services to reach a critical mass of consumers compared to other self-service channels such as Internet banking, telephone banking, or ATMs (Brown et al., 2003). Overall, results show a great improvement in adoption of cell phone banking compared to past years. Perceptions of risk and security concerns appear to slow the adoption rate. While banking institutions have done a lot in launching cell phone banking, focussing attention on in-house promotion and customer demonstrations of cell phone banking may further improve adoption rate.

\section{References}

Agarwal, R. and Prasad, J. (1998). A conceptual and operational definition of personal innovativeness in the domain of information technology. Information Systems Research, 9 (2): 204-215. http://dx.doi.org/10.1287/isre.9.2.204

Bicen, H. \& Cavus, N. (2010). The most preferred network sites by students. Procedia Social $\begin{array}{llll}\text { and Behavioural } & \text { Sciences, } & 2 & \text { (2010): }\end{array}$ http://dx.doi.org/10.1016/j.sbspro.2010.03.958

Blumberg, B., Cooper, D.R., \& Schindler, P.S. (2008). Business Research Methods. London: McGraw-Hill.

Brown, I., Cajee, Z., Davies, D., \& Stroebel, S. (2003). Cell phone banking: predictors of adoption in South Africa - an exploratory study. International Journal of Information Management, Vol. 23 (2003): 381-394. http://dx.doi.org/10.1016/S0268-4012(03)00065-3

Business Wire. (2010). The number of total subscribers in South Africa will increase from 42.4 million in 2007 to 48.5 million in 2010. [Online]. Available at: http://www.allbusiness.com/media-telecommunications/telecommunications/7312555-1.html

Calder, B.J., Phillips, L.W., \& Tybout, A.M. (1981). Designing Research for Application. The Journal of Consumer Research. Vol. 8 (2): 197-207. http://dx.doi.org/10.1086/208856

Central Intelligence Agency. (2010). World Factbook: South Africa. [Online]. Available at: https://www.cia.gov/library/publications/the-world-factbook/geos/sf.html [Accessed 22 June 2010].

Devlin, J.F. (1995). Technology and innovation in retail banking distribution. International Journal of Bank Marketing, 13 (4): 19 - 25. http://dx.doi.org/10.1108/02652329510082915

Devlin, J. \& Yeung, M.C.H. (2003). Insights into Customer Motivations for Switching to Internet Banking, The International Review of Retail, Distribution and Consumer Research, 
13 (4): 375-392. http://dx.doi.org/10.1080/0959396032000129480

Field, A. (2009). Discovering Statistics using SPSS. London: Sage Publications.

Hooper, V. \& Zhou, Y. (2007). Addictive, dependent, compulsive? A study of mobile phone usage. $20^{\text {th }}$ Bled eConference eMergence: Merging and Emerging Technologies, Processes, and Institutions Bled, Slovenia, June $4-6$.

International Telecommunications Union. (2011). ICT Data and Statistics. [Online], Available at: http://www.itu.int/ITU-D/ict/statistics/ [Accessed 12 January 2011].

Jayamaha, R. (2008). The Impact of IT in the Banking Sector. [Online] Available at: http://www.bis.org

Kumar, A. \& Gupta, H. (2008). Branchless Banking and Financial Inclusion, Silicon India, August 2008: 40

Meuter, M.L., Bitner, M.J., Ostrom, A.L., \& Brown, S.W. (2005). Choosing among Alternative Service Delivery Modes: An Investigation of Customer Trial of Self-Service Technologies. The Journal of Marketing, 69 (2): 61-83. http://dx.doi.org/10.1509/jmkg.69.2.61.60759

Mobi Thinking. (2010). The insider's guide to mobile Web marketing in South Africa. [Online]. Available at: http://www.mobithinking.com/interview-transcripts/the-insider-s-guide-mobile-web-marketin g-south-africa [Accessed 22 June 2010].

Mobile-Financial.com. (2009). The Secret to Mobile Banking Success Explained by Mobile Financial Industry Pioneer, Len Pienaar, First National Bank. Mobile-Financial.com, Thursday, July 30, 2009.

Pallant, J. (2010). SPSS Survival Manual: A step by step guide to data analysis using SPSS. London: Open University Press

Pienaar, L. (2009). FNB Mobile \& Transact Solutions FNB. Len Pienaar GMSA Workshop 15 April 2009.

Rogers, E. (1995). Diffusion of Innovations. $4^{\text {th }}$ edition. New York: The Free Press.

Robertson, T.S. (1967). The Process of Innovation and the Diffusion of Innovation. Journal of Marketing, 31 (1): 14-19. http://dx.doi.org/10.2307/1249295

Rugimbana, R \& Iversen, P. (1994). Perceived Attributes of ATMs and their Marketing Implications, International Journal of Bank Marketing, $12 \quad$ (2): 30. http://dx.doi.org/10.1108/02652329410052955

Seligman, L. (2006). Sensemaking throughout adoption and the innoation-decision process, European Journal of Innovation Management, $9 \quad 108$. http://dx.doi.org/10.1108/14601060610640050 
Shih, Y.-Y., \& Fang, K. (2004). The use of a decomposed theory of planned behavior to study Internet banking in Taiwan. Internet Research, 14(3): 213-223. http://dx.doi.org/10.1108/10662240410542643

SouthAfrica.info. (2007). SA Cell phone banking on the rise. [Online]. Available at: http://www.southafrica.info/business/trends/newbusiness/banking-211107.htm [Accessed 23 June 2010].

SouthAfrica.info. (2009). Mobile banking on the increase. [Online]. Available at: http://www.southafrica.info/business/trends/newbusiness/cell-171109.htm. [23 June 2010].

Tan, M., \& Teo, T. (2000). Factors influencing the adoption of Internet banking. Journal of the Association for Information Systems, 1(5): 1-42.

Taylor, S. \& Todd, P. (1995). Decomposition and crossover effects in the theory of planned behaviour: A study of consumer adoption intentions. International Journal of Research in Marketing, 12(1995): 137-155. http://dx.doi.org/10.1016/0167-8116(94)00019-K

Tornatzky, L.G. \& Klein, K.J. (1982). Innovation Characteristics and Innovation Adoption-Implementation: A Meta-Analysis of Findings. IEEE Transactions on Engineering Management, EM-29 (1): 28-45.

United Nations Children's Fund. (2007). Rapid Assessment of Cell Phones for Development. Women'snet. [Online]. Available at: http://www.women'snet.co.za

\section{Copyright Disclaimer}

Copyright reserved by the author(s).

This article is an open-access article distributed under the terms and conditions of the Creative Commons Attribution license (http://creativecommons.org/licenses/by/3.0/). 